\title{
Faironia difasciculata, a new gymnosperm from the Early Carboniferous (Mississippian) of Montagne Noire, France.
} Anne-Laure Decombeix*, Jean Galtier and Brigitte Meyer-Berthaud Botanique et bioinformatique de l'architecture des plantes (UMR 5120 CNRSCIRAD), TA40/PS2, CIRAD, Boulevard de la Lironde, 34398 Montpellier cedex 5, France

\begin{abstract}
A new taxon of probable gymnosperm affinities is described from the base of the Carboniferous (Mississippian, Middle Tournaisian) of Montagne Noire, southern France. It is based on a permineralised stem showing vascular and cortical tissues, and one attached petiole base. Faironia difasciculata gen. et sp. nov. shows the combination of a broad eustele and dense wood with a multifascicular leaf trace, originating from two non-adjacent axial strands. The Kalymma-type petiole base resembles that of the calamopityan pteridosperms but anatomy of the stele, wood and phloem more closely compares to that of early arborescent gymnosperms such as Pitus, Eristophyton or Megalomyelon the taxonomic position of which needs to be re-evaluated. Faironia is the sixth genus of seed plant affinities based on stems reported from the Montagne Noire deposits that, to date, comprise the most diverse assemblage of permineralised seed plant remains from just above the Devonian/Carboniferous boundary.
\end{abstract}

Keywords: Mississippian, Early Carboniferous; early gymnosperm; permineralised stem; petiole base; eustele; dense wood.

\footnotetext{
* Corresponding author: Fax: +33467615668

E-mail addresses: anne-laure.decombeix@cirad.fr (AL. Decombeix), jean.galtier@cirad.fr (J. Galtier), meyerberthaud@cirad.fr (B. Meyer-Berthaud)
} 


\section{Introduction}

The discovery of the lycopsid cone Lepidostrobus brownii by Schimper (Schimper, 1870) was the starting point of palaeobotanical investigation of the Lydiennes Formation of Montagne Noire (southern France). More than thirty taxa representing lycopsids, sphenopsids, ferns and lignophytes are presently known from plant fragments preserved as permineralisations or, rarely, as compressions. Lignophytes (i.e. progymnosperms and seed plants) represent an essential component of this Mid-Tournaisian flora and, particularly, stems and leaves of pteridosperm affinities are the most common fossils with a high proportion of calamopityan axes (Galtier et al., 1988). The abundance of vegetative remains of these plants in contrast to the rarity of possible corresponding fertile organs (Galtier and Rowe, 1989, 1991; Rowe and Galtier, 1990) is noteworthy.

Within the context of a study on Early Carboniferous lignophytes we describe in this paper a new specimen from the Tournaisian of Montagne Noire which presents an original combination of characters. Although this specimen has previously been cited and figured in two papers (Galtier, 1988, Figure 3.10 F; and "New taxon 1" in Galtier and Meyer-Berthaud, 2006), no formal description has yet been given.

Following the seed plant precursors (Gerrienne et al., 2004) and earliest seed plants of Devonian age (Fairon-Demaret and Scheckler, 1987; Rothwell et al., 1989; Serbet and Rothwell, 1992), there are more than forty taxa of putative seed plants of Early Carboniferous age known as anatomically preserved stems. Their reproductive structures being not clearly identified, these plants (with the exception of Heterangium) are not used by phylogenetic analyses (e.g. Doyle and Donoghue, 1992; Rothwell and Serbet, 1994). However they document an impressive diversification of their vegetative morphology, habit and size while their systematic position remains unclear. The new plant described in this paper combines features known in different groups of lignophytes and it significantly increases our understanding of early seed plants diversity.

\section{Materials and methods}

The Lydiennes Formation corresponds to sedimentary deposits in a shallow sea and consists of alternating beds of argilites and radiolarian cherts containing 
phosphatic nodules. Horizons containing plant fossils are considered middle Tournaisian in age (Tn2a-Tn2b) based on the conodonts (Galtier et al., 1988). The fossils are found loose in the matrix or occasionally included in the nodules. Specimen MN 266, described in this study, is an anatomically preserved stem included in a nodule that was collected on a natural outcrop, near $S^{t}$ Nazaire de Ladarez (Hérault, France).

The specimen was about $7 \mathrm{~cm}$ long and $5 \mathrm{~cm}$ wide; it was cut in 5 segments labeled A, B, C, D, and E. The organic matter being partly replaced by minerals, standard peel sections were of poor quality; therefore the specimen was studied using polished surfaces and wafers under reflected light, and by thin sections.

Observations were carried out using an Olympus BO61 stereomicroscope and an Olympus BX60 microscope. Photographs were made with an Olympus DP12 Microscope Digital Camera System and processed using Adobe Photoshop 6.0. Drawings of the transverse sections and of the leaf emission pattern were made with a Wild camera lucida attached on a stereomicroscope. Measurement of cells and tissues were conducted using SigmaScan software. Mean dimensions are given for one hundred measurements of each parameter.

The specimen and slides are kept in the AMAP Laboratory, Paleobotanical Collections, Université Montpellier II.

\section{Systematic palaeobotany}

Faironia gen. nov.

Diagnosis: Stem with primary and secondary vascular tissues and primary cortex. Eustele consisting of numerous discrete axial strands of primary xylem at the periphery of a broad circular pith. Ratio of primary xylem diameter to stem diameter high (about 1:2). Leaves helically arranged. Each leaf initially supplied by two traces originating separately from two non-adjacent axial strands. The paired leaf traces divide in the cortex supplying the petiole base with at least six vascular bundles. Axial primary xylem strands sometimes separated from the secondary xylem by parenchyma. Axial strands and leaf trace bundles mesarch. Metaxylem tracheids with scalariform to multiseriate bordered pitting on all walls. Secondary xylem tracheids with multiseriate bordered pits on radial walls. Rays uni to quadriseriate, not high. Secondary phloem present, including fibres. Narrow cortex consisting of an inner 
zone of parenchyma with sclerotic nests and an outer zone of sparganum-type fibre bundles.

Type species: Faironia difasciculata sp. nov.

Faironia difasciculata sp. nov. (Plates I-III)

Diagnosis: Stem with a circular eustele $21 \mathrm{~mm}$ wide, composed of more than 40 axial strands and incipient leaf traces. Primary xylem strands peripheral, in contact with the secondary xylem, or separated from the secondary xylem by one-four, rarely more, layers of parenchyma cells. Primary xylem strands mesarch, $80-280 \mu \mathrm{m}$ in diameter consisting of metaxylem tracheids up to $50 \mu \mathrm{m}$ wide and very small protoxylem elements. Homogeneous pith of polygonal parenchyma cells 60-294 $\mu \mathrm{m}$ wide and up to $250 \mu \mathrm{m}$ high. Tracheids of secondary xylem rectangular to polygonal, 14-67 $\mu \mathrm{m}$ (average $39 \mu \mathrm{m}$ ) in transverse section. Multiseriate pits $11 \mu \mathrm{m}$ in average diameter with inclined elliptical apertures. Rays uni-to multiseriate (up to 4 cells and $92 \mu \mathrm{m}$ wide), expanded in the innermost part of secondary xylem, relatively short (up to 28 cells and $650 \mu \mathrm{m}$ high). Ray parenchyma cells procumbent, rectangular, 62-101 $\mu \mathrm{m}$ long radially, $18 \mu \mathrm{m}$ wide tangentially and $30 \mu \mathrm{m}$ high. Secondary phloem with axial elements of parenchyma (20-35 $\mu \mathrm{m}$ wide), ray cells (17-34 $\mu \mathrm{m}$ wide), probable sieve cells, and fibres 12-43 $\mu \mathrm{m}$ wide and 274-495 $\mu \mathrm{m}$ long. Secondary phloem surrounded by a peripheral zone of parenchyma containing groups of large and short thick-walled cells (up to $70 \mu \mathrm{m}$ wide). Parenchymatous cells of inner cortex compressed with cells 120-230 $\mu$ m wide tangentially and 35-65 $\mu \mathrm{m}$ wide radially. In petiole base, ground tissue of isodiametric cells $129 \mu \mathrm{m}$ in diameter, and scattered sclerotic nests up to $200 \mu \mathrm{m}$ in diameter. Outer cortex of sparganum type $0.5 \mathrm{~mm}$ thick. Initial pair of leaf traces widely separated (about $5 \mathrm{~mm})$ at the periphery of the pith with at least four axial strands in the interval. Production of the pair of leaf traces asymmetrical, one leaf trace diverging first. Each leaf trace at first circular, $250 \mu \mathrm{m}$ wide with 1 protoxylem strand, becoming radially elongated (310x400 $\mu \mathrm{m}$ in transverse section) with division of the protoxylem strand when crossing the wood. In the inner cortex each leaf trace enlarging to form a $600 \times 1000 \mu \mathrm{m}$ wide bundle that divides twice resulting in a petiole vascular supply of six bundles. The two lateral bundles of the petiole vascular supply larger with four or more protoxylem strands. Tracheids of leaf traces up to $67 \mu \mathrm{m}$ in diameter, pitted on all walls. Petiole base $2.5 \mathrm{~cm}$ broad tangentially. 
Holotype: Specimen MN 266 (Plates I-III).

Type locality: Outcrop at "Puech Capel", south of $\mathrm{S}^{\mathrm{t}}$ Nazaire de Ladarez, Hérault, southern France (see map in Scott et al., 1984, figure 18b).

Horizon: nodule in radiolarian chert from the Lydiennes Formation of Montagne Noire; mid Tournaisian age ( $\operatorname{Tn} 2 \mathrm{a}-\mathrm{Tn} 2 \mathrm{~b})$.

Repository: Specimen and slides provisionally stored in the AMAP Laboratory, CIRAD, are part of the Paleobotanical collections, Service des Collections, Université Montpellier II, France.

Etymology: Derivation of the generic name: in honour of our distinguished colleague Dr. Muriel Fairon-Demaret to whom the present volume is dedicated in the year of her official retirement. Derivation of the specific epithet: refers to the double origin of the leaf trace.

\section{Description}

\subsection{General features}

Faironia is represented by a single specimen of anatomically preserved stem showing one petiole base attached (Plate I, 1; Fig. 1). It measures $6.3 \mathrm{~cm}$ long and about $3.4 \mathrm{~cm}$ in diameter. The centre of the specimen displays a prominent eustele with a large number of discrete primary xylem strands at the periphery of a broad parenchymatous pith. The ratio of stelar tissue diameter to total stem diameter, petiole base excluded, is around 1:2 (calculated from section illustrated in Fig. 1C). The surrounding ring of wood is dense, of the "pycnoxylic" type. A few elements of the secondary phloem are preserved. The cortex is narrow with an outer zone of the sparganum-type. There is no evidence of a periderm. Leaf traces depart in pairs. The petiole base vascular supply consists of 6 bundles arranged tangentially.

\subsection{Stele}

In the proximal part of the specimen that shows no sign of compression, the eustele is broadly circular in transverse section (Plate I, 2; Fig.1B). It is $2.1 \mathrm{~cm}$ wide and comprises about 45 mesarch primary xylem strands regularly distributed around a pith exclusively composed of parenchymatous cells.

Pith cells are polygonal in transverse section (Plate I, 4). The central cells display a wide range of size and include the largest elements. Peripheral cells are smaller 
(Plate I, 3). In longitudinal section, pith cells are rectangular to polygonal and some are arranged in short vertical rows (Plate I, 5). Mean dimensions are $149 \mu \mathrm{m}$ wide $(60-294 \mu \mathrm{m}) \times 144 \mu \mathrm{m}$ high $(75-250 \mu \mathrm{m})$. The two to four outermost rows of pith cells in contact with the wood comprise narrower elements $(50-90 \mu \mathrm{m}$ wide, $120-150$ $\mu \mathrm{m}$ high).

In cross section, the mesarch primary xylem strands are circular, triangular, or tangentially elongated and range from 80 to $280 \mu \mathrm{m}$ in diameter. They either lie in contact with the secondary xylem (Plate I, 3) or are immersed in the outer part of the pith. In the latter case, they are separated from the secondary xylem by 1-4 layers of parenchyma cells, rarely more (Plate I, 6, 7). An accurate delineation of the immersed xylem strands is often difficult. The largest, outermost, tracheids of metaxylem have thin walls and their diameter is about the same as that of the surrounding parenchyma cells (Plate I, 7). Immersed strands look generally smaller in diameter than those against the secondary xylem. Their number is about equal to that of strands in contact with the wood. Tangential pairs of immersed strands (Plate I, 6) and the elongate shape of some peripheral strands (Plate I, 3) suggest that they may divide during their course. The available material has not permitted us to reconstruct the vertical course of the primary xylem strands. We suspect but cannot demonstrate that the peripheral and immersed strands are part of the same axial strands that have a sinuous course and get in contact with the secondary xylem when about to produce a leaf trace. The occurrence of paired strands lying in a radial to oblique-radial plane at the periphery of the pith is related to leaf trace departure (see below) (Plate III, 1). In the primary xylem strands, protoxylem tracheids identified from their small diameter in cross section are 7-9 $\mu \mathrm{m}$ wide. Metaxylem tracheids are a little smaller than the secondary xylem tracheids with an average diameter of 27 $\mu \mathrm{m}(15-50 \mu \mathrm{m})$. In longitudinal section, their walls display scalariform thickening to multiseriate bordered pitting (Plate I, 8).

\subsection{Secondary xylem}

The secondary xylem is up to $6 \mathrm{~mm}$ thick, devoid of growth rings and composed of secondary xylem tracheids and parenchymatous rays. Secondary xylem tracheids are polygonal in cross section (Plate II, 2). At $5 \mathrm{~mm}$ from the pith both their average radial and tangential diameters are $39 \mu \mathrm{m}$ with respective maximal values of $58 \mu \mathrm{m}$ and $67 \mu \mathrm{m}$. In radial section tracheid walls display 2-4 rows of crowded bordered 
pits (Plate II, 5). Pits are hexagonal, range from 6-17 $\mu \mathrm{m}$ (average: $11 \mu \mathrm{m}$ ) in diameter, and show inclined elliptical apertures.

In transverse section rays separate 3-16 rows of tracheids and a large number cross the wood entirely. Their widening when close to the pith (Plate I, 3) results mostly from the enlargement of their cells. A tangential section, at $1 \mathrm{~mm}$ from the pith, shows rays $1-4$ cells broad (up to $92 \mu \mathrm{m}$ wide) and short, not exceeding 28 cells and $650 \mu \mathrm{m}$ high (Plate II, 3, 4); the average size for 100 rays is 1.5 cell broad and 6.5 cells high. About $60 \%$ are uniseriate. Parenchyma ray cells display variable shapes. In tangential section, they are $18 \mu \mathrm{m}$ broad and $30 \mu \mathrm{m}$ high in average dimensions. In radial section they are longer $(62-101 \mu \mathrm{m})$ than high. Cross-fields display crowded oval pits arranged in two horizontal rows.

\subsection{Cambium and secondary phloem}

Between the secondary xylem and inner cortex, a 300-500 $\mu \mathrm{m}$ wide zone represents the location of the vascular cambium and phloem (Plate II, 1). The inner part of the zone consists of three types of poorly preserved thin-walled elements among which are scattered groups of small radially aligned thick-walled cells (Plate II, 6-7). The latter cells range $12-43 \mu \mathrm{m}$ in diameter, are elongated in longitudinal section (274-495 $\mu \mathrm{m}$ high); and represent fibers (Plate II, 7, 8). Among the thinwalled cells, those that are elongated in longitudinal section may represent sieve cells; the shorter ones, with transverse walls, form the axial parenchyma. The third type of thin-walled elements is represented by $17-34 \mu \mathrm{m}$ wide ray cells that are radially elongated in transverse section and best seen when crossing groups of fibers (Plate II, 7). This inner part is interpreted as the secondary phloem. Cells of the vascular cambium, identifiable in radial longitudinal section by their narrow diameter, may be observable at the periphery of the secondary xylem.

The outer part of the zone consists of parenchyma cells and groups of large thickwalled cells with no particular orientation in transverse section. The thick-walled cells are up to $70 \mu \mathrm{m}$ in diameter, appear short in longitudinal section and represent sclereids (Plate II, 6, 8). The composition and spatial arrangement of the cells in this outer part suggest that it was not produced by the cambium.

\subsection{Cortex}


The cortex is preserved in about one-third of the stem circumference. Except in the petiole base, it is characteristically very narrow, about $1 \mathrm{~mm}$ thick in transverse section (Fig. 1A-C, Plate II, 1). The part of the inner cortex against the phloem zone comprises large parenchyma cells measuring up to $130 \mu \mathrm{m}$ in diameter that appear isodiametric to moderately compressed in transverse section. The outer part of the inner cortex comprises tangentially stretched cells $(120-230 \times 35-65 \mu \mathrm{m})$ that are significantly more compressed than those of the inner part (Plate II, 1). In radial longitudinal section all parenchyma cells measure up to $220 \mu \mathrm{m}$ high. The inner cortex has occasional sclerotic nests of sclereids.

The outer cortex is of the sparganum-type. In transverse section, radial bands of sclerenchyma fibres about $500 \mu \mathrm{m}$ in radial dimension (Plate II, 1; Plate III, 8) alternate with zones of parenchyma cells. Sclerenchyma cells range 33-80 $\mu \mathrm{m}$ in diameter and the ratio of sclerenchyma to parenchyma is variable, about 1:0.8. It is higher in the petiole base.

\subsection{Leaf trace emission and petiole base}

Leaf traces are emitted in pairs (Fig. 2). The two traces depart at a different vertical level, the one opposite the direction of the ontogenetic spiral (a, Fig.2A-C) diverging more proximally. As a result their pattern of branching as seen in transverse sections is asymmetrical (Fig. 2D).The two traces of a pair arise along a radial-oblique plane from two strands separated by 4 to 5 axial strands (Fig. 2A, B). Trace emission is generally associated with the occurrence of a "deeply immersed" (about $600 \mu \mathrm{m}$ from the inner edge of the secondary xylem) strand (Plate III, 1). Successive pairs of traces are emitted according to a spiral phyllotaxy (Fig. 1) at an angle of $130-140^{\circ}$ corresponding to a Fibonacci series. Successive leaf traces are numbered 1 to 8 in acropetal order on Fig. 1A-D; however, due to the destruction of a large part of the cortex, traces 2, 3 and 5 are missing. The internode length is about $20 \mathrm{~mm}$. If correctly interpreted this correspond to a $2 / 5$ phyllotaxis.

Initially each trace consists of a xylem bundle about $250 \mu \mathrm{m}$ wide in transverse section, with a single mesarch protoxylem strand (a, Fig. 2A; b, Fig. 2B; Plate III, 1). As it crosses the secondary xylem, the trace is accompanied by parenchyma on its adaxial side. It gets radially elongated $(310 \mu \mathrm{m}$ tangentially, $400 \mu \mathrm{m}$ radially in transverse section) and displays 2 radially oriented mesarch strands of protoxylem (b, Fig. 2C; Plate III, 2). In the inner cortex, each trace of a pair is proximally oval with 
a diameter that has increased up to $0.6 \times 1 \mathrm{~mm}$ (a, Fig. 2C). Each trace then becomes curved and produces a bundle laterally (Plate III, 4). The petiole vascular supply at this stage comprises four bundles, two small abaxial and two large lateral ones (Fig. 2D). This is followed by a further division of the two lateral bundles to form a petiolar vascular supply of 6 bundles (Fig. 2D; Plate III, 5).

The 6 petiolar bundles are arranged in a C-shaped pattern, the concave part of which faces the centre of the stem (Fig. 1A; Plate III, 5). They are radially elongated with various shapes and sizes ( 0.8 to $2.4 \mathrm{~mm}$ in radial dimension). The two lateral ones are larger, more elongate and contain four or more protoxylem strands (aI and bI, Fig. 2D; Plate III, 7). It is possible that each of these lateral bundles divides again higher up inside the petiole to result in a leaf vascular supply of 8 or more bundles. Of the four other bundles, the two median ones which resulted from the first division are larger than the other two (aIII and bIII, Fig. 2D). They are radially elongated and contain two to three protoxylem strands (Plate III, 6). The vascular bundle tracheids are 16-67 $\mu \mathrm{m}$ wide in cross section (average $37 \mu \mathrm{m}$ ). Their walls display scalariform thickenings to multiseriate pitting (Plate III, 3).

In the most complete transverse section, the petiole base measures about $2.5 \mathrm{~cm}$ tangentially (Plate III, 5). The six vascular bundles are embedded in a parenchymatous ground tissue and surrounded by sclerotic nests that are relatively small (up to $200 \mu \mathrm{m}$ diameter) and consist of a central core of small thick-walled cells surrounded by large radiating parenchyma cells.

A continuous zone of sclerenchyma fibres developed between the stem cortex and the leaf base.

\section{Discussion}

Two sets of questions are raised by Faironia difasciculata. One is related to the nature of the organ represented by the type specimen, its position in the plant, and the type of growth form we can infer for the species. The second deals with its taxonomic affinities and significance in relation to the patterns of diversification of the early seed plants.

\subsection{Nature of the type specimen}


The wide pith and relatively large petiole base comprising 6 vascular bundles indicate that the Faironia stem produced a large primary body during its ontogenetic trajectory, a character expected for main axes, but that cannot be ruled out for distal branches as shown by the twigs of Pitus included in the species P. dayi (Gordon, 1935). If the size of the pith is correlated with the morphogenetic potentialities of the apex, a trait assessed for a wide range of plants (Eggert, 1961, 1962; Scheckler, 1978), we can expect that the Faironia axis described in this paper had a high potential in terms of primary growth, quantified by the number and/or size of organs produced and the large number of axial primary xylem strands present.

The narrow ring of wood and persistence of a petiole base, in turn, are suggestive of a young axis, in an early phase of development. But the fact that wood production, even limited in this specimen, resulted in the extensive crushing of the cortex without provoking the initiation of a periderm suggests that secondary growth was limited. In $P$. dayi by contrast, a periderm is described at all levels of the distal twigs except the very terminal portions with a narrow pith (Gordon, 1935; Speck and Rowe, 1994). For Faironia, the lack of periderm is a severe constraint in terms of stem longevity suggesting that the type specimen was probably a determinate axis. Whether it represents the main stem (trunk) of a short-lived plant, or the determinate distal branch of a long-lived tree that expressed a periderm at proximal levels, but not distally, is an unanswered question that requires additional material to be resolved.

\subsection{Taxonomy}

The specimen exhibits the unique combination of a eustelic organization and dense wood with a multifascicular leaf trace, originating from two non-adjacent axial strands, which justifies its assignment to a new genus. It represents a stem with a wide pith and limited development of wood providing useful information both on the primary body and secondary growth potential of the plant. Collectively, these characters allow detailed comparison with stems of Late Devonian and Early Carboniferous lignophytes presumed to be seed plants based on their compound megaphylls (Table 1). The earliest known seed plants, of Late Devonian age, are characterised by slender protostelic stems that do not exceed $25 \mathrm{~mm}$ in diameter and bear highly divided fronds (Matten et al., 1980, 1984; May and Matten, 1983; Fairon-Demaret and Scheckler, 1987; Rothwell et al., 1989). During the Tournaisian, about 40 taxa based on anatomically preserved stems with presumed seed plant 
affinities document an impressive diversification of morphology and habit with at least two size classes (Galtier, 1988; Galtier and Meyer-Berthaud, 2006). The majority are interpreted as small semi-self supporting plants with a generally protostelic stem, manoxylic wood and a prominent hypodermis. They correspond to members of the calamopityan, buteoxylalean and lyginopteridalean pteridosperms. In contrast, arborescent forms like Pitus resemble the archaeopteridalean progymnosperms in having a eustelic primary vascular system comprising numerous discrete sympodial strands and the potential for developing large amounts of pycnoxylic wood. Following Galtier (1992) and Galtier and Meyer-Berthaud (2006), a manoxylic wood comprises wide tracheids (up to $150 \mu \mathrm{m}$ or more in diameter) and rays that are both broad (more than 5 cells) and tall (up to 200 cells); pycnoxylic woods are characterized by narrow tracheids (less than $50 \mu \mathrm{m}$ in diameter) and short rays.

\subsubsection{Comparison with early arborescent seed plants}

An exhaustive list of Mississippian (Early Carboniferous) pteridosperm taxa of putative arborescent habit has recently been compiled by Galtier and MeyerBerthaud (2006). It includes a number of relatively well-known genera, most originally described from late Tournaisian and Viséan Scottish localities (e.g. Pitus, Eristophyton, Bilignea, Stanwoodia, Endoxylon) together with more obscure taxa like the Tournaisian genera Aporoxylon, Pycnoxylon, Cauloxylon and Megalomyelon. To date, Pitus and Eristophyton, which exhibit trunks exceeding $25 \mathrm{~cm}$ in diameter, are the most widely represented ones, both geographically and stratigraphically (Decombeix et al., 2005). Faironia presents a number of similarities with these early putative arborescent seed plants: (1) the stelar organization, which consists of a broad eustele comprising a large number of discrete primary xylem strands at the periphery of a circular parenchymatous pith (about 40 strands around a $20 \mathrm{~mm}$ wide pith in Faironia); (2) the small diameter of the primary and secondary xylem tracheids, with wood tracheids (average diameter $39 \mu \mathrm{m}$ in Faironia) exceeding metaxylem tracheids (average diameter $27 \mu \mathrm{m}$ in Faironia); (3) the relatively small rays of secondary xylem (average 1.5 cell wide and 6.5 cells high in Faironia); (4) the complex secondary phloem consisting of fibres, different types of thin-walled cells and ray cells. Interestingly, these characters are also shared with the arborescent progymnosperm genus Archaeopteris. However our specimen which has a petiole 
base still attached does not show any evidence of a periderm, a tissue that has been recognized in Pitus, Eristophyton, Stanwoodia, Endoxylon, and Bilignea (Scott, 1902, 1924; Gordon, 1935; Galtier et al., 1993a)

Among the five species of Pitus reported by Gordon (1935), P. dayi comprises stems comparable in size to the Faironia specimen. These range from $8-25 \mathrm{~mm}$ in diameter and are regarded by Gordon as "small twigs, presumably the ultimate branches of some large stems". The stelar organization in Faironia resembles that of Pitus, with a number of primary xylem strands separated from the secondary xylem. But our plant does not show the deeply immersed strands that characterize all species of Pitus including P. dayi and that occur in all types of axes in the genus, except possibly the largest ones (Gordon, 1935). Faironia also differs from Pitus by its smaller rays, double leaf trace and vascular supply of the petiole base, with six bundles instead of the three reported in Pitus dayi. At last, a periderm is initiated very early in the young twigs of $P$. dayi (Speck and Rowe, 1994), a condition that is not realized in Faironia.

The new plant is also similar to Eristophyton waltonii (Lacey, 1953) in stelar characteristics (broad stele comprising primary xylem strands separated from the secondary xylem), size of individual leaf traces, and in its multifascicular petiole anatomy resembling that of Lyginorachis waltonii, the probable petiole of Eristophyton waltonii according to Long (1987). However E. waltonii differs by its broader rays, sclerotic nests in the pith, simple origin of leaf traces and occurrence of pitting on the tangential walls of the secondary xylem tracheids (Galtier and Scott, 1990; Lacey, 1953).

Faironia is characterised by its double leaf trace origin, a feature recognized in Pycnoxylon leptodesmon, Cauloxylon ambiguum and Megalomyelon myriodesmon (Cribbs, 1938, 1939, 1940), three taxa founded on broader decorticated woody stems but unfortunately lacking information on cortex and petiole anatomy. Megalomyelon and Cauloxylon exhibit the broadest eusteles with up to 100 primary xylem strands around a pith exceeding $3 \mathrm{~cm}$ in diameter. This may reflect a maximum epidogenetic phase of development in these arborescent plants that correspond to values without equivalent in present woody gymnosperms of coniferous type. In both Megalomyelon and Cauloxylon, the leaf traces are emitted by two non-adjacent axial strands with 14 intercalary strands. Another similarity with Faironia is the location of the primary xylem strands in a "submarginal zone", detached from the secondary xylem but 
never in the central part of the pith like in Pitus. Differences include the size of rays, up to 90 cells high in both species and up to 7 cells wide in Cauloxylon, and the presence of numerous sclerotic nests in the pith of Cauloxylon. One cannot exclude the possibility that Faironia was a young stage of development of a plant that resulted in a tree showing the characteristics of Megalomyelon or Cauloxylon.

Other putative arborescent gymnosperms of Tournaisian age like Archeopitys (Scott and Jeffrey, 1914), Eristophyton beinertianum (Scott, 1902), Bilignea solida (Scott, 1924) differ by features of stelar organisation whilst information on cortex and petiole anatomy is lacking in the first two taxa; $B$. solida also differs in its simple Lyginorachis-type of petiole (Bateman and Rothwell, 1990).

\subsubsection{Comparison with Calamopityaceae}

Faironia shows a multifascicular petiole base similar to the Kalymma-type petioles considered as characteristic of the Calamopityaceae (Barnard and Long, 1975). In addition, the leaf trace is double in origin, a rare feature also recognised in the calamopityan genera Diichnia (Beck et al., 1992; Read, 1936), Galtiera (Beck and Stein, 1987), Stenomyelon bifasciculare (Meyer-Berthaud, 1984), Calamopitys americana (Galtier and Beck, 1995) and Calamopitys schweitzeri (Galtier, MeyerBerthaud and Beck, 1993b). However our new plant differs by the origin of the paired leaf traces from two non-adjacent axial strands (instead of two adjacent strands in Diichnia and a single strand in Galtiera, Stenomyelon and Calamopitys). Most important, Faironia is also distinct from Diichnia, Calamopitys and related genera in major features of the stele, wood, phloem and cortex organization (Table 1): (1) in calamopityan pteridosperms, the steles range from solid (Stenomyelon) or parenchymatised protosteles (Calamopitys) to small eusteles (Diichnia and some Calamopitys); small eusteles are polygonal and show a small number of primary xylem strands (Galtier, 1988), which is a very different situation from that in Faironia; (2) the primary and secondary xylem tracheids are large in calamopityans, generally exceeding $100 \mu \mathrm{m}$ in diameter, with metaxylem tracheids broader than wood tracheids, the reverse of the situation in Faironia; (3) in calamopityans the rays are both high and wide; in combination with the large diameter of tracheids, this results in a typical manoxylic wood quite distinct from the wood observed in our new plant; (4) thick-walled cells and fibres have not yet been described in the phloem of calamopityans; (5) at last, the broad cortex and small eustele in the calamopityans 
result in low values (1/5 to $1 / 10)$ of the stele diameter/stem diameter ratio (Galtier, 1988), which contrasts with the situation in Faironia (1/2).

In addition to the calamopityans, the other early seed plants, including Elkinsia (Rothwell et al., 1989) and putative members of the Tournaisian Lyginopteridaceae and Buteoxylonaceae (Barnard and Long, 1973, 1975), are characterised by protostelic stems with a manoxylic wood and are therefore quite distinct from Faironia.

\subsubsection{Systematic affinities}

Faironia is another example of an early pteridosperm stem that is difficult to classify, especially in the absence of fertile parts. The available information on Kalymma-type petiole anatomy would allow us to refer this plant to the Calamopityaceae within the Lyginopteridales according to the proposal of Barnard and Long (1975). However we do not agree with the use of a single character of petiole anatomy as a basis for a family level taxon. This is supported by the fact that multifascicular petioles have been recognised in Heterangium and Eristophyton without resulting in the attribution of these taxa to the Calamopityaceae. As discussed above our new plant shows a significant number of features in common with other early seed plants like Pitus and Eristophyton suggesting closer affinities with the latter than with the Calamopityaceae. However, these taxa have been attributed to the Lyginopteridaceae by Barnard and Long (1975), also on the basis of their Lyginorachis-type petiole anatomy, and this cannot be applied to our new plant. It is evident that the systematics of Late Devonian/Early Carboniferous seed fern families are badly in need of revision (Serbet and Rothwell, 1992). Barnard and Long (1975) used the order Lyginopteridales (including the four families Lyginopteridaceae, Calamopityaceae, Medullosaceae, Buteoxylonaceae) for the group normally referred to as the Pteridospermopsida. In contrast Rothwell et al. (1989) used the class Pteridospermopsida, including the Elkinsiales and the families Lyginopteridaceae, Calamopityaceae, Buteoxylonaceae and Stenokoleaceae while Taylor and Taylor (1993) refer all the seed ferns to the division Pteridospermophyta.

Work in progress on other members of early Carboniferous arborescent seed plants (Decombeix et al., 2005; Galtier and Meyer-Berthaud, 2006) is expected to result in the definition of a new group of plants. In this paper Faironia is provisionally referred to as incertae sedis within the Pteridospermopsida. 


\section{Conclusion}

Faironia is a new genus of presumed seed plant affinities founded on a single stem presenting a previously unknown combination of anatomical characters. Faironia shares foliar traits (e.g. petioles of Kalymma-type, double origin of leaf traces) with the Calamopityaceae but its vascular body, which comprises a broad eustele and a dense wood, is similar to that of the arborescent pteridosperms of the Pitus-Eristophyton complex to which we suspect that they are more closely related. Considering stem growth trajectory, Faironia also appears unique. It is presently unknown whether the limited production of wood and lack of periderm in the typespecimen characterizes the entire plant or just distal short-lived branches. In any case, Faironia is characterized by a broader primary body than the Calamopityaceae, but has a more constrained secondary growth than the arborescent pteridosperms of Pitus-type.

The unique combination of characters present in Faironia increases our knowledge of the anatomical diversity of Pitus-like seed plants, of which about 10 genera are currently recognised in the Tournaisian of Europe and USA (Galtier and Meyer-Berthaud, 2006).

Faironia is the sixth genus of seed plant affinities based on stems reported from the middle Tournaisian of Montagne Noire and the third, with Lyginopitys and Triichnia, to be unknown elsewhere (Galtier et al., 1988; Galtier \& Beck, 1992). The deposits of Montagne Noire document one of the most diverse assemblages of spermatophytes of Mississippian age. In regard to the paucity of localities yielding plants around the D/C boundary, the ongoing study of these deposits is of primary importance for understanding the patterns of evolution of seed plants, at a time when the progymnosperm genus Archaeopteris that dominated Late Devonian forests, was becoming extinct. 


\section{Acknowledgements}

We thank J. Guiraud for technical assistance, N. Rowe for discussion on Faironia mechanical properties and P. Gerrienne for inviting us to contribute to the present volume in honour of Muriel Fairon-Demaret. 


\section{References}

Barnard, P. D. W., Long, A. G., 1973. On the structure of a petrified stem and some associated seeds from the Lower Carboniferous rocks of East Lothian, Scotland. Trans. R Soc. London 69, 91-108.

Barnard, P. D. W., Long, A. G., 1975. Triradioxylon-a new genus of Lower Carboniferous petrified stems and petioles together with a review of the classification of early Pterophytina. Trans. R. Soc. Edinburgh 69, 231-250.

Bateman, R. M., Rothwell, G. W., 1990. A reappraisal of the Dinantian floras at Oxroad Bay, East Lothian, Scotland.1. Floristics and the development of whole-plant concepts. Trans. R. Soc. Edinburgh: Earth Sciences 81, 127-159.

Beck, C. B., Stein, W. E., 1987. Galtiera bostonensis, gen. et sp. nov., a protostelic Calamopityacean from the New Albany Shales of Kentucky. Can. J. Bot. 65, 348-361.

Beck, C. B., Galtier, J., Stein, W. E. J., 1992. A reinvestigation of Diichnia Read from the New Albany Shales of Kentucky. Rev. Palaeobot. Palynol. 75, 1-32.

Cribbs, J. E., 1938. A new fossil plant from the Reed Springs Formation of Southwestern Missouri. Am. J. Bot. 25, 311-321.

Cribbs, J. E., 1939. Cauloxylon ambiguum, gen. et sp. nov., a new fossil plant from the Reed Springs Formation of southwestern Missouri. Am. J. Bot. 26, 440449.

Cribbs, J. E., 1940. Structure of fossil stem with Pityean affinity from the Reed Springs Formation of Missouri. Bot. Gaz. 101, 582-597.

Decombeix, A.-L., Meyer-Berthaud, B., Rowe, N. P., Galtier, J., 2005. Diversity of large woody lignophytes preceding the extinction of Archaeopteris: new data from the middle Tournaisian of Thuringia (Germany). Rev. Palaeobot. Palynol. 137, 69-82.

Doyle, J. A., Donoghue, M. J., 1992. Fossil and seed plant phylogeny reanalyzed. Brittonia 44, 89-106.

Eggert, D. A., 1961. The ontogeny of Carboniferous arborescent Lycopsida. Palaeontographica 108B, 43-92.

Eggert, D. A., 1962. The ontogeny of Carboniferous arborescent Sphenopsida. Palaeontographica 110B, 99-127. 
Fairon-Demaret, M., Scheckler, S. E., 1987. Typification and redescription of Moresnetia zalesskyi Stockmans, 1948, an early seed plant from the Upper Famennian of Belgium. Bull. Ins. R. Sci. Nat. Belg., Sci. Terre 57, 183-199.

Galtier, J., 1988. Morphology and Phylogenetic Relationships of Early Pteridosperms in Beck, C.B. (Ed.), Origin and Evolution of Gymnosperms. Columbia University Press. New-York pp. 135-176.

Galtier, J., 1992. On the earliest arborescent gymnosperms. Cour. Forsch.-Inst. Senckenberg 147, 119-125.

Galtier, J., Beck, C. B., 1992. Triichnia, a new eustelic calamopityacean from the Lower Carboniferous of France. Palaeontographica 224B, 1-16.

Galtier, J., Beck, C. B., 1995. A reinvestigation of Calamopitys americana with a description of two species from the Lower Carboniferous of U.S.A. and France. Palaeontographica 237B, 75-111.

Galtier, J., Rowe, N. P., 1989. A primitive seed-like structure and its implications for early gymnosperm evolution. Nature 340, 225-227.

Galtier, J., Rowe, N. P., 1991. A new permineralised seed-like structure from the basalmost Carboniferous of France. Neues Jahrb. Geol. Paläontol. Abh. 183, 103-120.

Galtier, J., Meyer-Berthaud, B., 2006. The diversification of early arborescent seed ferns. J. Torrey Bot. Soc. 133 (1): 7-19.

Galtier, J., Scott, A. C., 1990. On Eristophyton and other gymnosperms from the Lower Carboniferous of Castelton Bay, East Lothian, Scotland. Geobios 23, 5-19.

Galtier, J., Meyer-Berthaud, B., Rowe, N. P., 1988. Tournaisian plants from the "lydiennes" Formation of the Montagne Noire (France). Cour. Forsh.-Inst. Senckenberg 100, 109-117.

Galtier, J., Meyer-Berthaud, B., Beck, C. B., 1993b. Large Calamopitys stems from the Tournaisian of France. Palaeontographica 230, 59-79.

Galtier, J., Brown, R. E., Scott, A. C., Rex, G. M., Rowe, N. P., 1993a. A late Dinantian flora from Weaklaw, East Lothian, Scotland. Spec. Pap. Paleontol. $49,57-74$.

Gerrienne, P., Meyer-Berthaud, B., Fairon-Demaret, M., Streel, M., Steemans, P., 2004. Runcaria, a Middle Devonian Seed Plant Precursor. Science 306, 856858. 
Gordon, W. T., 1935. The genus Pitys, Witham, emend. Trans. R. Soc. Edinburgh 58, 279-311.

Lacey, W. S., 1953. Scottish Lower Carboniferous Plants: Eristophyton waltonii sp. nov. and Endoxylon zonatum (Kidston) Scott from Dumbartonshire. Ann. Bot. 68, 579-596.

Long, A. G., 1987. Observations on Eristophyton Zalessky, Lyginorachis waltonii Calder, and Cladoxylon edromense sp. nov. from the Lower Carboniferous Cementstone group of Scotland. Trans. R. Soc. Edinburgh 78, 73-84.

Matten, L. C., Lacey, W. S., May, B. I., Lucas, R. C., 1980. A megafossil flora from the uppermost Devonian near Ballyheigue, Co. Kerry, Ireland. Rev. Palaeobot. Palynol. 29, 241-251.

Matten, L. C., Tanner, W. R., Lacey, W. S., 1984. Additions to the silicified Upper Devonian/Lower Carboniferous flora from Ballyheigue, Ireland. Rev. Palaeobot. Palynol. 43, 303-320.

May, B.I. and Matten L.C., 1983. A probable pteridosperm from the uppermost Devonian, near Ballyheigue, County Kerry, Ireland. Bot. J. Linn. Soc. 86: 103123

Meyer-Berthaud, B., 1984. Stenomyelon, from the Upper Tournaisian of the Montagne Noire (France). Canadian Journal of Botany 62 (11), 2297-2307.

Read, C. B., 1936. The flora of the New Albany shale, 1. Diichnia kentuckiensis, a new representative of the Calamopityeae. U.S. Geol. Surv. Prof. Pap. 185H, 149-161.

Rothwell, G. W., Serbet, R., 1994. Lignophyte Phylogeny and the Evolution of Spermatophytes: A Numerical Cladistic Analysis. Syst. Bot. 19 (3), 443-482.

Rothwell, G. W., Scheckler, S. E., Gillespie, W. H., 1989. Elkinsia gen. nov., a Late Devonian gymnosperm with cupulate ovules. Bot. Gaz. 150, 170-189.

Rowe, N. P., Galtier, J., 1990. A Lower Carboniferous Plant Assemblage from La Serre (Montagne Noire, France). Part II. Gymnosperms. Rev. Palaeobot. Palynol. 63, 91-115.

Scheckler, S. E., 1978. Ontogeny of progymnosperms. II. Shoots of Upper Devonian Archaeopteridales. Can. J. Bot. 56 (24), 3136-3170.

Schimper, W., 1870. Traité de Paléontologie végétale. Tome 2. Paris. 
Scott, A. C., Galtier, J., Clayton, G., 1984. Distribution of anatomically-preserved floras in the Lower Carboniferous in Western Europe. Trans. R. Soc. Edinburgh 75, 311-340.

Scott, D. H., 1902. On the primary structure of certain Palaeozoic stems with the Dadoxylon type of wood. Trans. R. Soc. Edinburgh 40 (II), 331-365.

Scott, D. H., 1924. Fossil plants of the Calamopitys type, from the Carboniferous rocks of Scotland. Trans. R. Soc. Edinburgh 53 (III), 569-596.

Scott, D.H. and Jeffrey E.C., 1914. On fossil plants, showing structure, from the base of the Waverley Shale of Kentucky. Phil. Trans. R. Soc. B 205: 345-354

Serbet, R., Rothwell, G. W., 1992. Characterizing the most primitive seed ferns. I. A reconstruction of Elkinsia polymorpha. Int. J. Plant. Sci. 153 (4), 602-621.

Speck, T., Rowe, N. P., 1994. Biomechanical Analysis of Pitus dayi: Early Seed Plant Vegetative Morphology and Its Implications on Growth Habit. J. Plant Res. 107, 443-460.

Taylor, T. N., Taylor, E. L., 1993. The biology and evolution of fossil plants. Prentice Hall, Englewood Cliffs, New Jersey, USA. 


\section{Plate legends}

Plate I. Faironia difasciculata gen. et sp. nov. from the Early Mississippian of France

- General view and primary vascular tissues

1. Transverse section of stem with petiole base (p) corresponding to Fig. 1b, MN266BS01.

2. General view of stele with circular parenchymatous pith; arrowheads outline the stele border, transverse section. MN266-BS01

3. Transverse section of the pith-secondary xylem boundary showing two primary xylem strands in contact with the secondary xylem, the one at arrow tangentially elongated. MN266-AS01.

4. Parenchymatous pith cells in transverse section. MN266-AS01.

5. Parenchymatous pith cells in longitudinal section. MN266-C2LR02.

6. Tangential pair of slightly immersed primary xylem strands, transverse section. MN266-AS01.

7. Small immersed primary xylem strand, transverse section. MN266-AS01.

8. Scalariform pitting on primary xylem tracheids walls, longitudinal section. MN266-C2LR02

Plate II. Faironia difasciculata gen. et sp. nov. from the Early Mississippian of France - Secondary tissues and cortex.

1. Transverse section through the secondary xylem (X2), phloem (P2), inner cortex (IC) that comprises an external zone of compressed cells, and the sparganum outer cortex (OC). MN266-DIO1.

2. Transverse section of secondary xylem showing a triseriate and a uniseriate ray. MN266-BS01

3. Longitudinal tangential section through secondary xylem showing various ray sizes. MN266-CLT01.

4. Detail of rays, tangential section. MN266-CLT01.

5. Multiseriate pitting of the radial walls of secondary xylem tracheids. MN266C2LR02

6. Transverse section showing the external part of the secondary xylem (X2) and the phloem zone below, Sc: sclereids; arrow indicates radially aligned cells in the secondary phloem, MN266-BS01 
7. Detail of the secondary phloem showing a group of radially aligned fibres (f) and probable ray cells $(\mathrm{R})$, transverse section. MN266-BS01

8. Radial longitudinal section showing secondary xylem (X2) and phloem zone with fibers (f) and sclereids (Sc). MN266-C2LR02

Plate III. Faironia difasciculata gen. et sp. nov. from the Early Mississippian of France - Leaf trace emission.

Note: 'Leaf trace' refers to one trace of a pair.

1. Transverse section at the level of a leaf trace departure showing the leaf trace (uppermost strand, at LT), a strand lying radially just below the LT, and a "deeply" immersed strand at arrow. MN266-BS01.

2. Radially elongated leaf trace showing two protoxylem strands when crossing the wood, transverse section. MN266-EI01.

3. Radial ornamentation of the tracheid walls of the leaf trace. MN266-C2LR02.

4. Leaf trace dividing in the cortex; small abaxial bundle on the left, large lateral bundle on the right, transverse section. MN266-BS01.

5. General view of the petiole base in transverse section, X2: secondary xylem, roman numerals indicate the location of the 6 vascular bundles originating from two leaf traces, a and b. MN266-AS01

6. Small vascular bundle in the leaf base, with 2 protoxylem strands, transverse section. MN266-AS01.

7. Two bundles in the leaf base, the large lateral one (I) may divide again, transverse section. MN266-AS01.

8. Sparganum and non-distorted ground-tissue in the petiole base, transverse section. MN266-AS01. 


\section{Figure legend}

Fig.1 - Faironia difasciculata gen. et sp. nov. from the Early Mississippian of France Transverse sections in ascending order (A-D) of the stem illustrating the position of the vascular supplies to different leaves. Vascular supplies are numbered 1-8 following their order of emission along the ontogenetic spiral. Hypothesized location of leaves 2, 3 and 5 indicated in parentheses on figure B. (MN266; A: AS01, B: BS01, C: DI01, D: EI01).

Fig. 2 - Faironia difasciculata gen. et sp. nov. from the Early Mississippian of France

A-C: Camera lucida drawings at three successive levels illustrating the divergence of a pair of leaf traces a and b (MN266 BS01, DI01, EI01). D: Drawing of the successive stages of trace division leading to the formation of the petiole vascular supply (composite of traces to leaves 7,4 and 1). Bundles in the petiole base are numbered I-III for traces $a$ and $b$. 


\section{Table legend}

Table1. Faironia difasciculata gen. et sp. nov. from the Early Mississippian of France

Comparison of some significant anatomical characters in Faironia difasciculata and in some calamopityan and lyginopteridalean seed ferns. Cal eura: Calamopitys eurameriana, Cal sch: Calamopitys schweitzeri, Dii ken: Diichnia kentuckiensis, MN266: Faironia difasciculata, Eri wal: Eristophyton waltonii, Pit day: Pitus dayi, Meg myr: Megalomyelon myriodesmon.

sppro: super-parenchymatised protostele, e: eustele. 

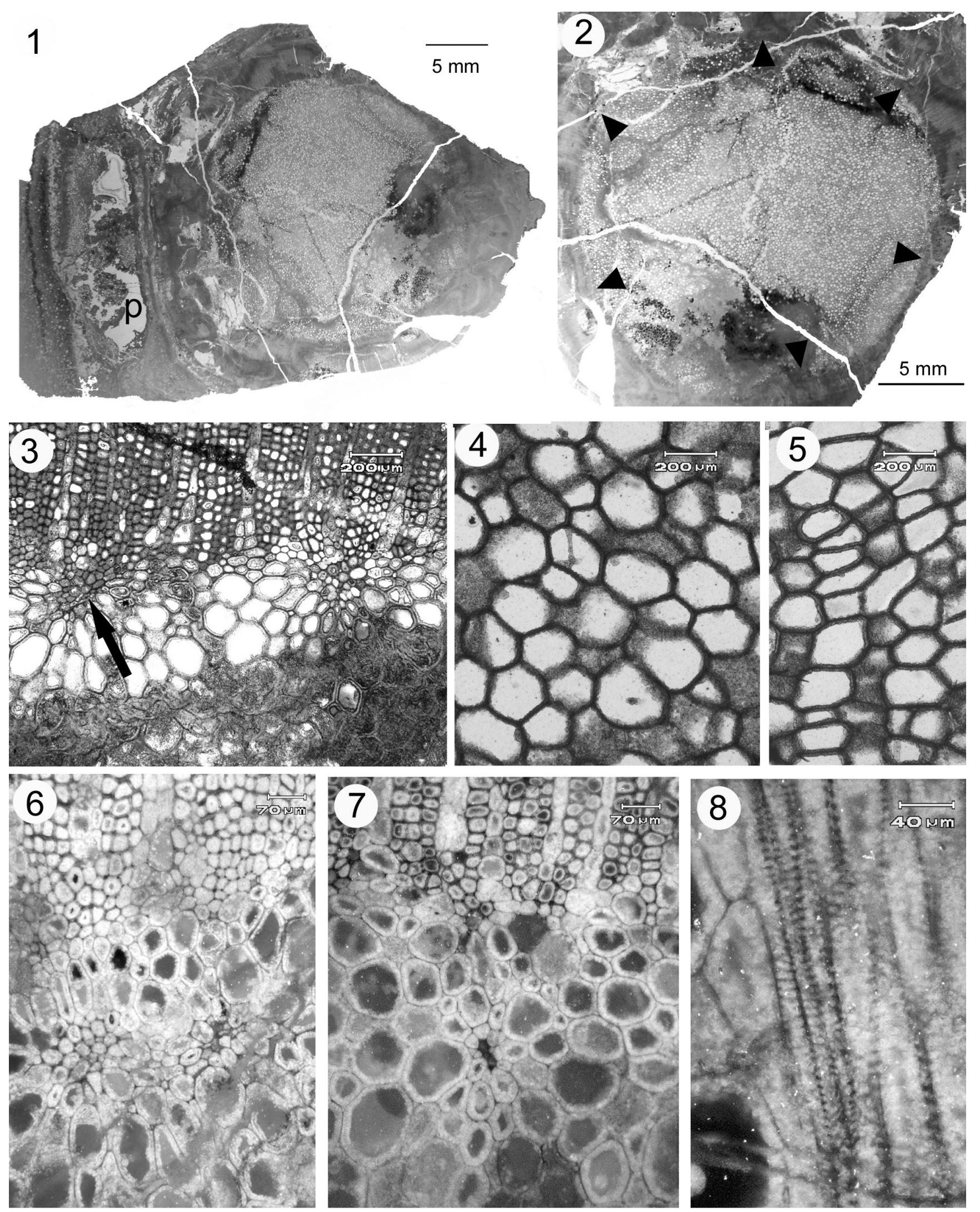

Plate I 

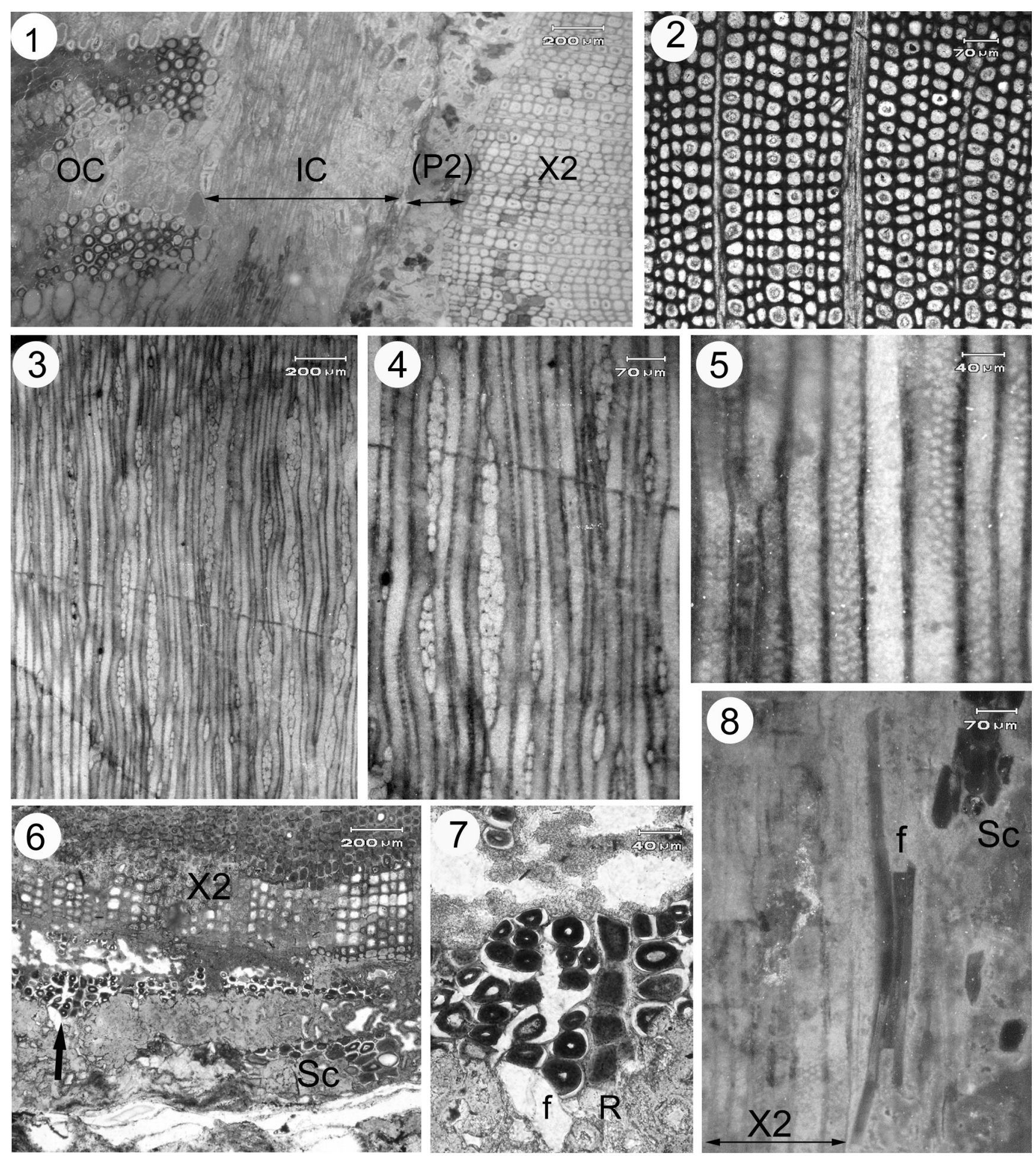

\section{Plate II}



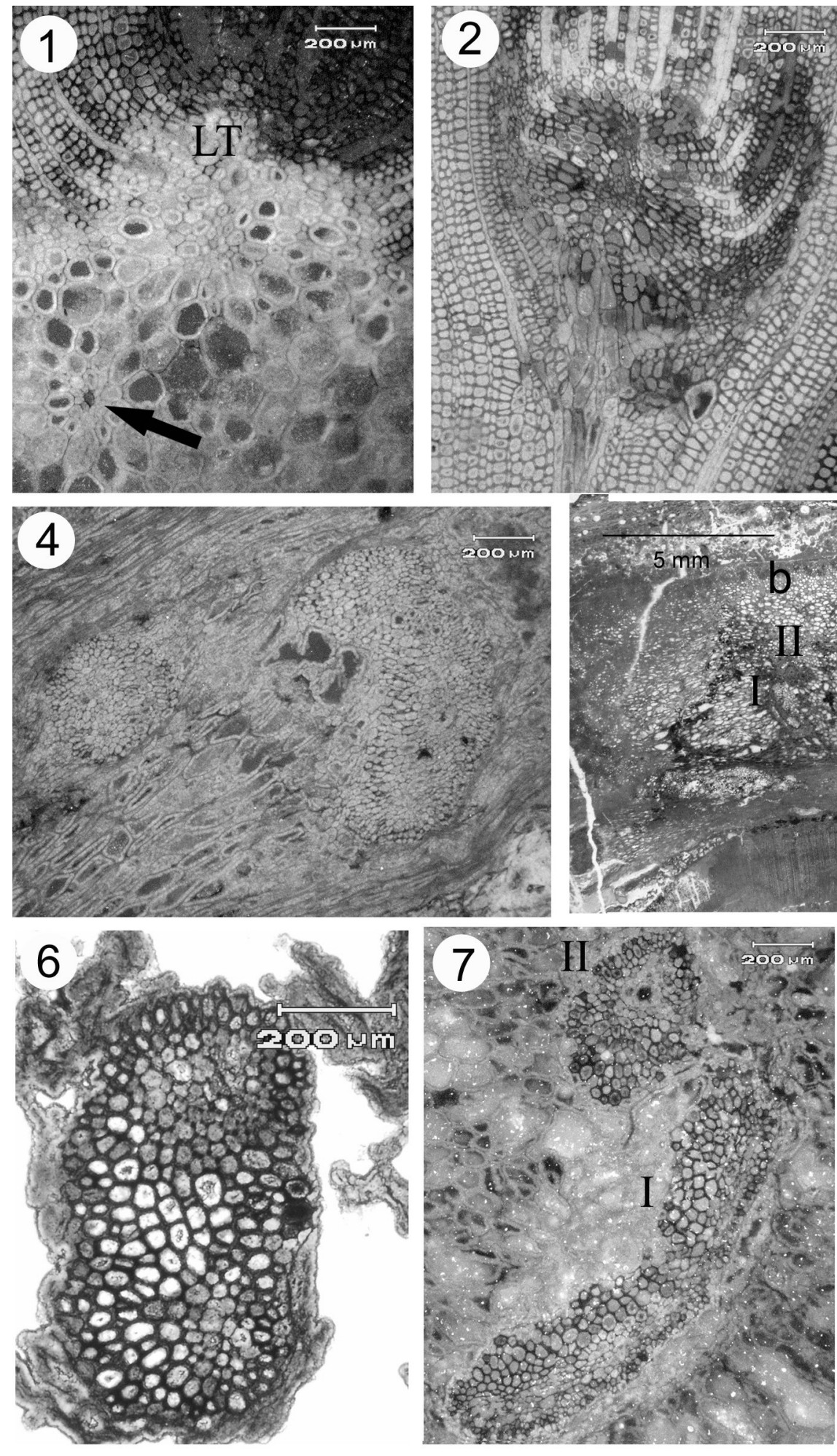
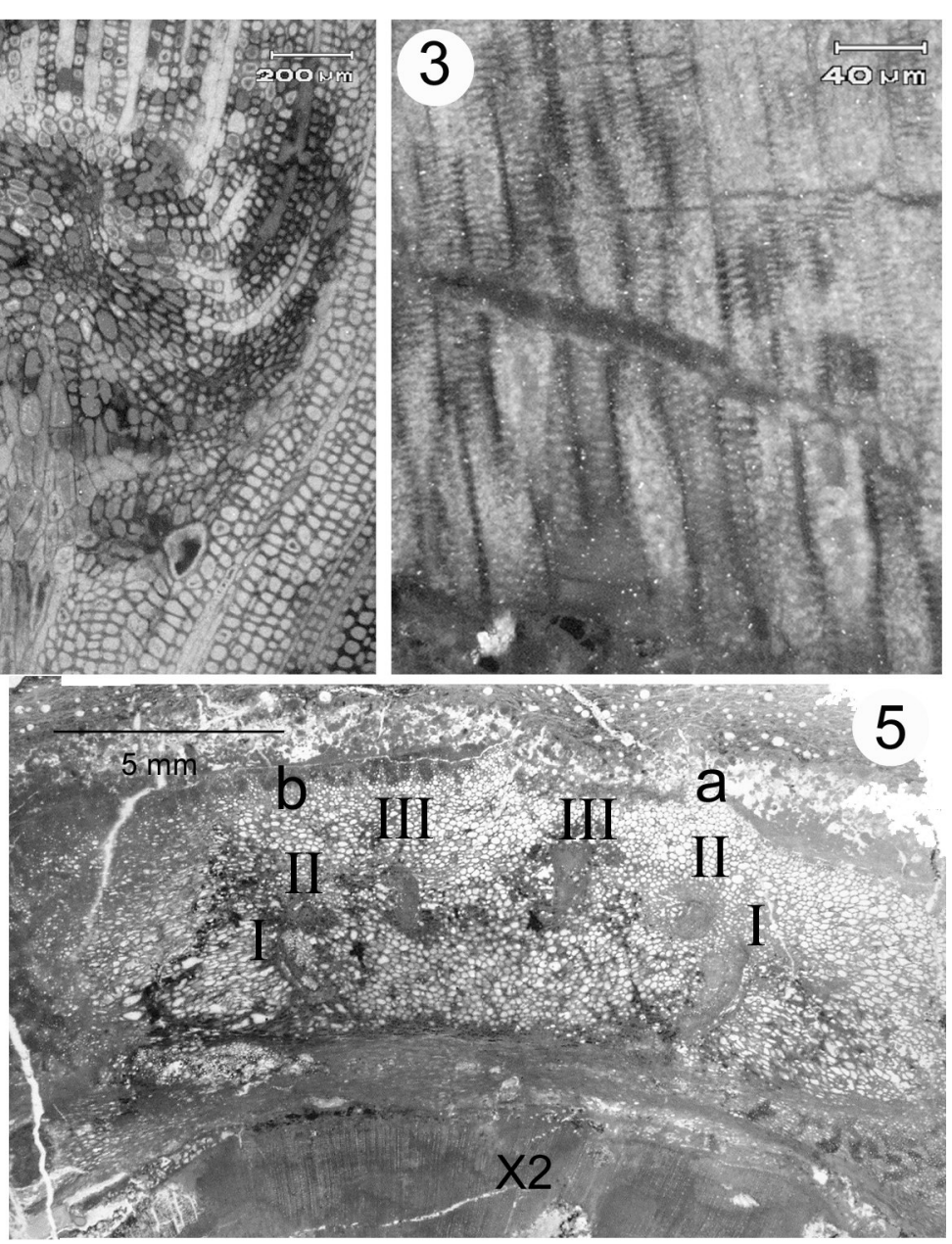

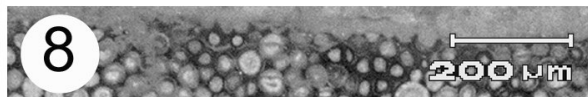
30308

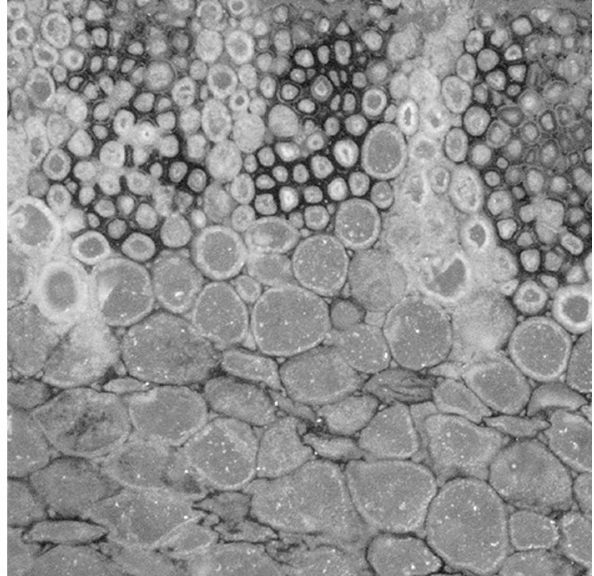

\section{Plate III}


A

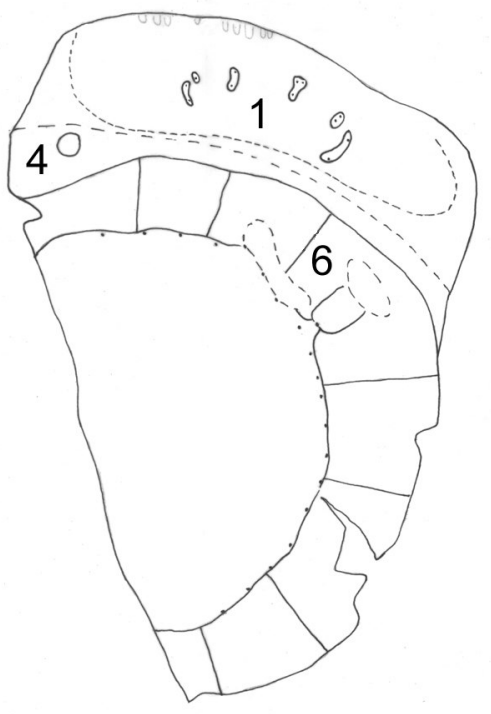

C

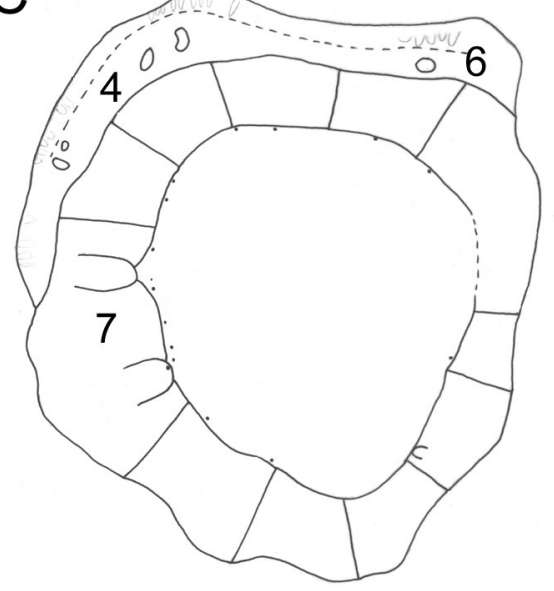

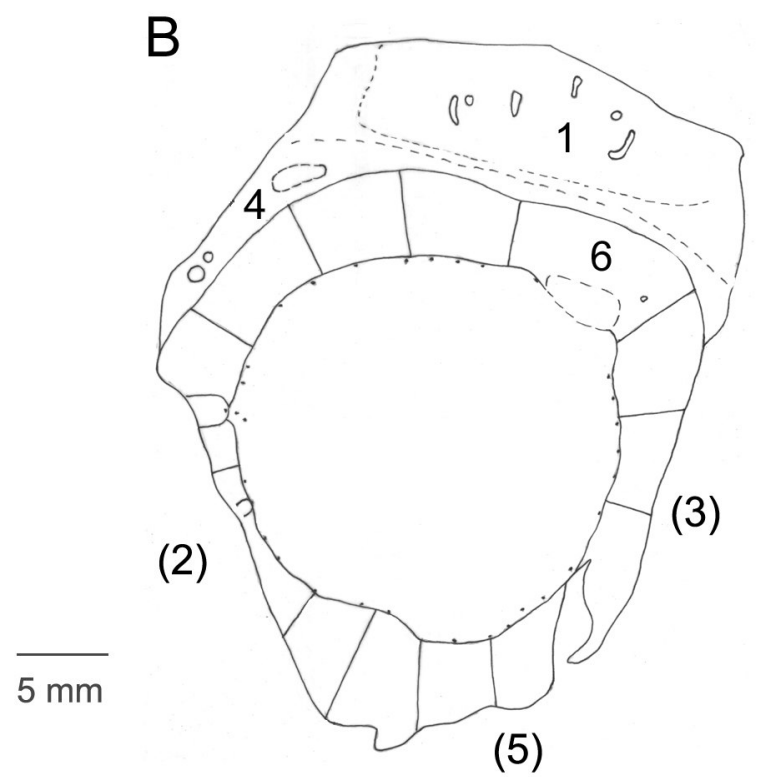

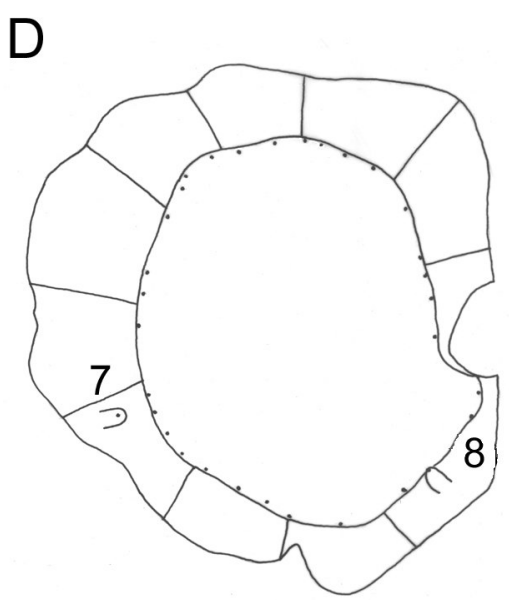

Fig. 1 


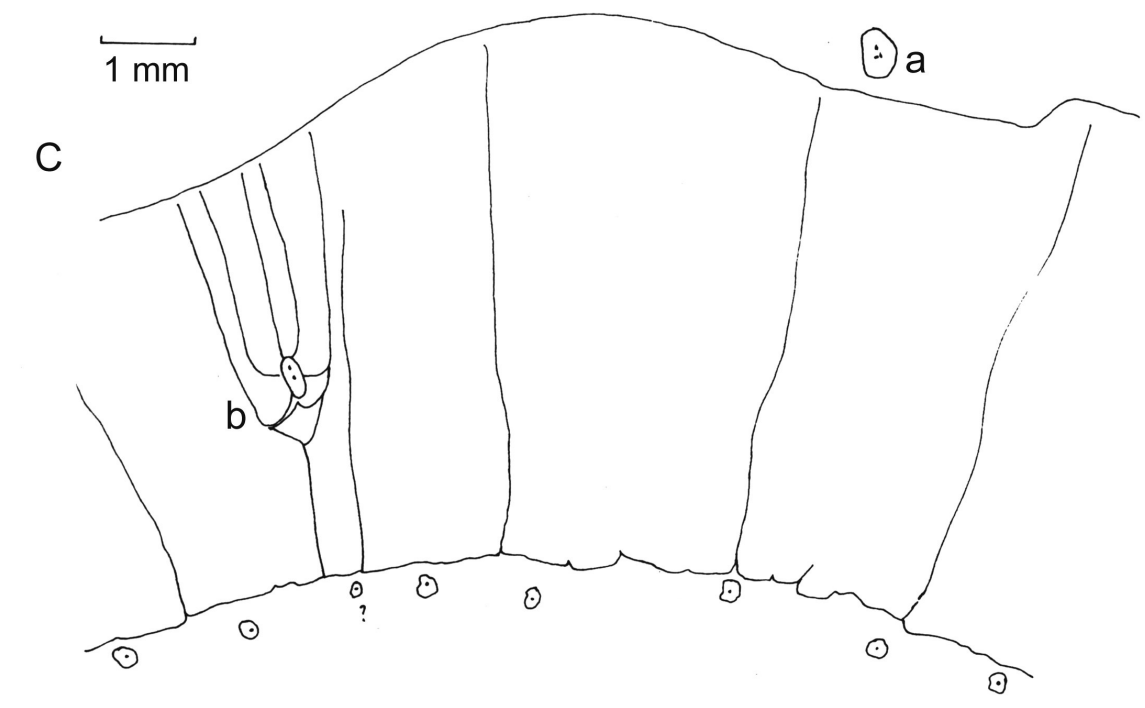

$\left.B\right|_{0} ^{B}$

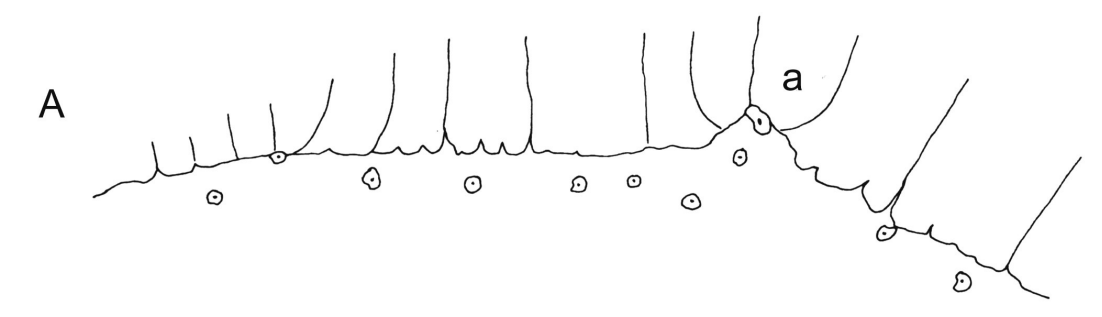

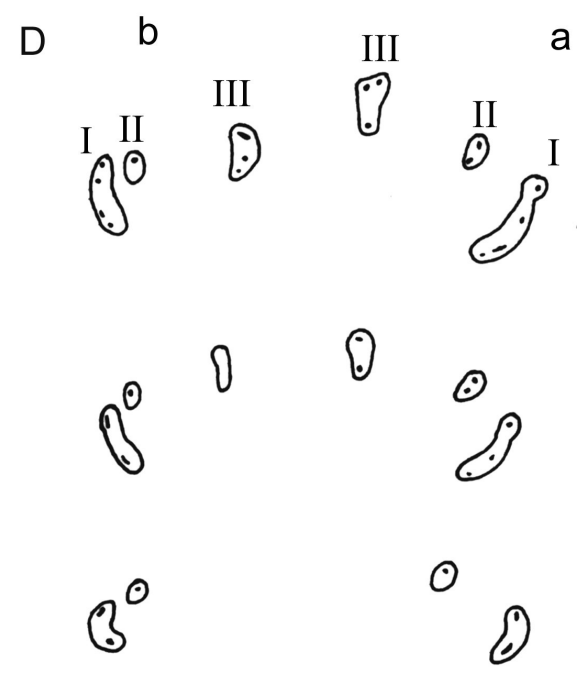
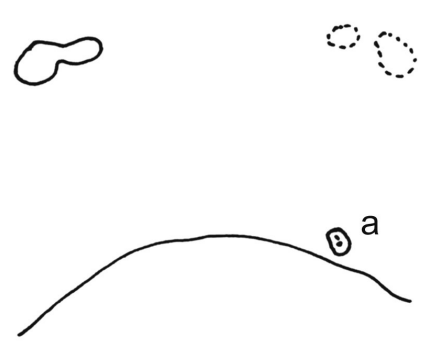

$a b$

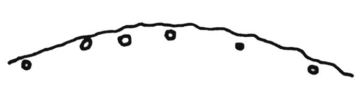

Fig. 2 


\begin{tabular}{|c|c|c|c|c|c|c|c|}
\hline & $\begin{array}{l}\text { Cal } \\
\text { eura }\end{array}$ & $\begin{array}{l}\text { Cal } \\
\text { sch }\end{array}$ & $\begin{array}{l}\text { Dii } \\
\text { ken }\end{array}$ & $\begin{array}{l}\text { MN } \\
266\end{array}$ & $\begin{array}{l}\text { Eri } \\
\text { wal }\end{array}$ & $\begin{array}{l}\text { Pit } \\
\text { day }\end{array}$ & $\begin{array}{l}\text { Meg } \\
\text { myr }\end{array}$ \\
\hline Wood thickness (mm) & 13 & 5 & 4.5 & 5.5 & $7-120$ & 6 & 28 \\
\hline Stele diameter $(\mathrm{mm})$ & 7 & 5 & 7 & 21 & $10-35$ & 11 & $50 \times 22$ \\
\hline Stele type & sppro & $\mathrm{e}$ & $\mathrm{e}$ & $\mathrm{e}$ & $\mathrm{e}$ & $\mathrm{e}$ & $\mathrm{e}$ \\
\hline Stele/stem diameter & $1 / 7$ & $1 / 10$ & $1 / 5.5$ & $1 / 1.5$ & & $1 / 2$ & \\
\hline Number of sympodial strands & 8 & 5 & 5 & 40 & $10-45$ & 30 & 100 \\
\hline $\begin{array}{l}\text { Metaxylem tracheids maximum } \\
\text { diameter }(\mu \mathrm{m})\end{array}$ & 240 & 240 & 208 & 50 & 50 & 30 & \\
\hline $\begin{array}{l}\text { Wood tracheids maximum } \\
\text { diameter }(\mu \mathrm{m})\end{array}$ & 160 & 100 & 108 & 70 & 70 & 65 & 60 \\
\hline $\begin{array}{c}\text { Maximum ray width (cells) } \\
\mu \mathrm{m}\end{array}$ & $\begin{array}{l}11 \\
210\end{array}$ & 8 & $\begin{array}{l}12 \\
208\end{array}$ & $\begin{array}{l}4 \\
80\end{array}$ & $\begin{array}{l}7 \\
150\end{array}$ & 6 & 3 \\
\hline $\begin{array}{c}\text { Maximum ray height (cells) } \\
\mathrm{mm}\end{array}$ & $\begin{array}{l}>100 \\
>5\end{array}$ & $\begin{array}{l}300 \\
4\end{array}$ & $\begin{array}{l}>100 \\
>2.7\end{array}$ & $\begin{array}{l}28 \\
0.6\end{array}$ & $\begin{array}{l}50 \\
1.4\end{array}$ & 36 & 90 \\
\hline Maximum number of pit rows & 7 & 4 & 8 & 4 & 5 & 4 & 3 \\
\hline $\begin{array}{l}\text { Secondary phloem without (-) or } \\
\text { with fibres (f) }\end{array}$ & - & - & - & $\mathrm{f}$ & $\mathrm{f}$ & $\mathrm{f}$ & \\
\hline $\begin{array}{l}\text { Origin of leaf trace } \\
\text { Intercalary strands }\end{array}$ & $\begin{array}{l}1 \\
-\end{array}$ & $\begin{array}{l}2 \\
-\end{array}$ & $\begin{array}{l}2 \\
-\end{array}$ & $\begin{array}{l}2 \\
4+\end{array}$ & $\begin{array}{l}1 \\
-\end{array}$ & $\begin{array}{l}1 \\
-\end{array}$ & $\begin{array}{l}2 \\
1-4\end{array}$ \\
\hline $\begin{array}{l}\text { Maximum number of bundles } \\
\text { per leaf base }\end{array}$ & 18 & 16 & 6 & 6 & $? 6$ & 3 & \\
\hline $\begin{array}{l}\text { Maximum width of petiole } \\
\text { vascular supply (mm) }\end{array}$ & 27 & 32 & 12 & $? 12$ & & 3 & \\
\hline Internode length $(\mathrm{mm})$ & $20-40$ & 34 & & 20 & 2 & & \\
\hline
\end{tabular}

